\title{
SYNTHESIS, CHARACTERIZATION AND CRYSTAL STRUCTURES OF BENZOHYDRAZONE COMPOUNDS DERIVED FROM 5-METHYLSALICYLALDEHYDE
}

\author{
XU-FENG MENGA ${ }^{A}$ WEI-NING LI ${ }^{B}$,JING-JUN MA $A^{A, *}$ \\ ${ }^{a}$ College of Sciences, Agricultural University of Hebei, Baoding 071001, P. R. China \\ ${ }^{b}$ Teaching Affairs Division, Agricultural University of Hebei, Baoding 071001, P. R. China
}

\begin{abstract}
A series of three new benzohydrazone derivatives, $N^{\prime}$ '-(2-hydroxy-5-methylbenzylidene)-4-methylbenzohydrazide (1), $N^{\prime}$-(2-hydroxy-5-methylbenzylidene)4-hydroxybenzohydrazide (2), and $N^{\prime}$-(2-hydroxy-5-methylbenzylidene)-4-dimethylaminobenzohydrazide (3), were prepared and characterized by elemental analysis, ${ }^{1} \mathrm{H}$ and ${ }^{13} \mathrm{C}$ NMR, and single crystal X-ray diffraction. Compound (1) crystallizes in the monoclinic space group $C 2 / c$ with unit cell dimensions $a=$ 27.421(1) $\AA, b=9.9843(4) \AA, c=24.302(1) \AA, \beta=119.416(2)^{\circ}, V=5795.7(5) \AA^{3}, Z=16, R_{1}=0.0520$, and $w R_{2}=0.1172$. Compound (2) crystallizes in the orthorhombic space group Pna2, with unit cell dimensions $a=9.511(2) \AA, b=9.866(2) \AA, c=13.871(3) \AA, V=1301.6(5) \AA^{3}, Z=4, R_{1}=0.0342$, and $w R_{2}=0.0912$. Compound (3) crystallizes in the monoclinic space group $C 2 / c$ with unit cell dimensions $a=26.957(2) \AA, b=10.0612(9) \AA, c=25.526(2) \AA, \beta=114.405(3)^{\circ}, V=$ $6304.5(10) \AA^{3}, Z=16, R_{1}=0.0532$, and $w R_{2}=0.1079$. X-ray diffraction indicated that the benzohydrazone molecules of the compounds display trans configuration with respect to the $\mathrm{C}=\mathrm{N}$ double bonds. The crystal structures of the compounds are stabilized by hydrogen bonds and weak $\pi \cdots \pi$ interactions.
\end{abstract}

Keywords Benzohydrazone $\cdot 5$-methylsalicylaldehyde $\cdot$ X-ray diffraction $\cdot$ hydrogen bonding $\cdot \pi \cdots \pi$ interaction

\section{INTRODUCTION}

Benzohydrazone derivatives with the typical functional groups $-\mathrm{CH}=\mathrm{N}-$ $\mathrm{NH}-\mathrm{C}(\mathrm{O})-$ are a kind of important compounds in biological and medical chemistry [1-3]. The compounds are usually synthesized from the condensation reaction between benzohydrazides and carbonyl-containing compounds. In the past decade, a number of benzohydrazone derivatives have been synthesized and investigated for their structures and biological applications [4-6]. Detailed study on the crystal structures seems to be essential for the understanding of the activities and applications of the compounds. However, to the best of our knowledge, benzohydrazone compounds derived from 5-methylsalicylaldehyde have seldom been reported. In this paper, the author reports the synthesis, characterization, and crystal structures of three new benzohydrazone derivatives, $\quad N^{\prime}$-(2-hydroxy-5-methylbenzylidene)-4-methylbenzohydrazide (1), $\quad N^{\prime}$-(2-hydroxy-5-methylbenzylidene)-4-hydroxybenzohydrazide (2), and $\quad N^{\prime}$-(2-hydroxy-5-methylbenzylidene)-4-dimethylaminobenzohydrazide (3), from the reaction of 5-methylsalicylaldehyde with various substituted benzohydrazides.

\section{EXPERIMENTAL}

Materials and Measurements

5-Methylsalicylaldehyde,

4-methylbenzohydrazide, 4-hydroxybenzohydrazide, and 4-dimethylaminobenzohydrazide were purchased from Aldrich. Methanol was commercially available and used without further purification. Elemental analyses $(\mathrm{C}, \mathrm{H}$ and $\mathrm{N})$ were performed on a Perkin-Elmer $2400 \mathrm{CHN}$ Elemental Analyzer. ${ }^{1} \mathrm{H}$ and ${ }^{13} \mathrm{C}$ NMR spectra were obtained from solution in DMSO- $d_{6}$ with $\mathrm{Me}_{4} \mathrm{Si}$ as internal standard using a Bruker AVANCE $500 \mathrm{MHz}$ analyzer.

Synthesis of (1)

5-Methylsalicylaldehyde $(1.0 \mathrm{mmol}, 0.136 \mathrm{~g})$ and 4-methylbenzohydrazide $(1.0 \mathrm{mmol}, 0.150 \mathrm{~g})$ were dissolved in methanol $(20 \mathrm{~mL})$. The mixture was stirred at room temperature for $30 \mathrm{~min}$ to give colorless solution. After keeping the solution in air for a few days, colorless block-shaped single crystals, suitable for X-ray diffraction, were formed. The crystals were isolated by filtration, washed with methanol and dried in air. Yield $0.18 \mathrm{~g}(67 \%)$. ${ }^{1} \mathrm{H}$ NMR (ppm): $\delta: 2.32-2.35(\mathrm{~d}, 6 \mathrm{H}), 6.92(\mathrm{~d}, 1 \mathrm{H}), 7.09(\mathrm{~d}, 1 \mathrm{H}), 7.41-7.53(\mathrm{~m}, 3 \mathrm{H}), 7.93(\mathrm{~d}$, $2 \mathrm{H}), 8.72(\mathrm{~s}, 1 \mathrm{H}), 10.62(\mathrm{~s}, 1 \mathrm{H}), 12.23(\mathrm{~s}, 1 \mathrm{H}) .{ }^{13} \mathrm{C} \mathrm{NMR}(\mathrm{ppm}): \delta: 21.5,116.7$, $118.6,127.3,129.2,129.7,130.7,131.2,133.0,140.9,145.8,159.0,162.9$.

Synthesis of (2)

Using 5-methylsalicylaldehyde and 4-hydroxybenzohydrazide $(1.0 \mathrm{mmol}$, $0.152 \mathrm{~g}$ ), and following exactly the same procedure as that described for (1), colorless block-shaped single crystals of (2) were obtained. Yield $0.22 \mathrm{~g}(81 \%)$. ${ }^{1} \mathrm{H}$ NMR (ppm): $\delta: 2.33(\mathrm{~s}, 3 \mathrm{H}), 6.85-6.92(\mathrm{~m}, 3 \mathrm{H}), 7.09(\mathrm{~d}, 1 \mathrm{H}), 7.45(\mathrm{~s}, 1 \mathrm{H})$, $7.87(\mathrm{~d}, 2 \mathrm{H}), 8.73(\mathrm{~s}, 1 \mathrm{H}), 10.55(\mathrm{~s}, 1 \mathrm{H}), 10.73(\mathrm{~s}, 1 \mathrm{H}), 11.87(\mathrm{~s}, 1 \mathrm{H}) .{ }^{13} \mathrm{C}$ NMR (ppm): $\delta$ : $21.5,115.8,116.7,118.6,125.1,128.8,130.7,131.6,133.0,145.8$,

\section{$158.7,161.2,163.0$}

Synthesis of (3)

Using 5-methylsalicylaldehyde and 4-dimethylaminobenzohydrazide (1.0 $\mathrm{mmol}, 0.179 \mathrm{~g}$ ), and following exactly the same procedure as that described for (1), colorless block-shaped single crystals of (3) were obtained. Yield $0.23 \mathrm{~g}$ (75\%). ${ }^{1} \mathrm{H}$ NMR (ppm): $\delta: 2.33$ (s, 3H), 3.07 (s, 6H), 6.89-6.95 (m, 3H), 7.09 $(\mathrm{d}, 1 \mathrm{H}), 7.46(\mathrm{~s}, 1 \mathrm{H}), 7.62(\mathrm{~d}, 2 \mathrm{H}), 8.73(\mathrm{~s}, 1 \mathrm{H}), 10.67(\mathrm{~s}, 1 \mathrm{H}), 12.05(\mathrm{~s}, 1 \mathrm{H})$ ${ }^{13} \mathrm{C}$ NMR (ppm): $\delta: 21.5,42.2,111.3,116.7,118.6,121.9,130.5,131.6,133.0$, $145.8,153.7,163.0$

X-ray crystallography

Suitable single crystals were carefully selected under a microscope. Crystal data for the compounds were collected on a Bruker SMART APEX II-CCD diffractometer at 298(2) $\mathrm{K}$ using graphite monochromated Mo K $\alpha$ radiation $(\lambda$ $=0.71073 \AA$ ). Cell parameters were obtained by the global refinement of the positions of all collected reflections. An empirical absorption correction was applied. The structures were solved by direct method and refined by full-matrix least-squares on $F^{2}$ using the SHELXL-97 software [7]. All the non-hydrogen atoms were refined anisotropically. The amino $\mathrm{H}$ atoms in the compounds were located from difference Fourier maps and refined isotropically, with $\mathrm{N}-\mathrm{H}$ distances restrained to $0.90(1) \AA$. The remaining $\mathrm{H}$ atoms were added theoretically. Some relevant crystallographic data and structure determination parameters are summarized in Table 1. Selected bond lengths and angles for the compounds are given in Tables 2.

\section{RESULTS AND DISCUSSION}

The compounds were readily prepared by the reaction of equimolar quantities of 5-methylsalicylaldehyde with 4-methylbenzohydrazide, 4-hydroxybenzohydrazide, and 4-dimethylaminobenzohydrazide, respectively, in methanol. The elemental analyses are in agreement with the empirical formulae given by the single crystal X-ray determination (Table 3). Single crystals of the compounds can easily be formed by slow evaporation of their methanol solutions. All the compounds are soluble in methanol, ethanol, acetonitrile, dichloromethane, and chloroform.

Crystal structure description of the compounds

Figs. 1, 2, and 3 give the perspective views of (1), (2), and (3), respectively, with the atomic labeling system. The asymmetric units of compounds (1) and (3) contain two molecules, while that of compound (2) contains only one molecule. All the bond lengths in the compounds are within normal ranges [8], and are comparable to those of the similar benzohydrazone compounds [9-11]. The bond lengths of C7-N1 and C23-N3 (for (1)), C8-N1 (for (2) and (3)), and $\mathrm{C} 25-\mathrm{N} 4$ (for (3)) confirm them as double bonds. The bond lengths of $\mathrm{C} 8-\mathrm{N} 2$ and C24-N4 (for (1)), C9-N2 (for (2) and (3)), C26-N5 (for (3)), and N1-N2 (for all the compounds), N3-N4 (for (1)), and N4-N5 (for (3)) are relatively short, suggesting some degree of delocalization in the acetohydrazide systems. 
The dihedral angles between the two benzene rings are $30.3(3)^{\circ}$ (molecule A) and 13.6(3) (molecule B) for $(1)$, $41.1(3)^{\circ}$ for $(2)$, and $17.0(3)^{\circ}($ molecule A) and $27.0(3)^{\circ}$ (molecule B) for (3). All the molecules of the compounds exist in trans configuration with respect to the $\mathrm{C}=\mathrm{N}$ double bonds of the central methylidene units.

Table 1. Crystal data for the compounds.

\begin{tabular}{|c|c|c|c|}
\hline Compounds & (1) & (2) & (3) \\
\hline Color/shape & colorless/block & colorless/block & colorless/block \\
\hline Empirical formula & $\mathrm{C}_{16} \mathrm{H}_{16} \mathrm{~N}_{2} \mathrm{O}_{2}$ & $\mathrm{C}_{15} \mathrm{H}_{14} \mathrm{~N}_{2} \mathrm{O}_{3}$ & $\mathrm{C}_{17} \mathrm{H}_{19} \mathrm{~N}_{3} \mathrm{O}_{2}$ \\
\hline Formula weight & 268.31 & 270.28 & 297.35 \\
\hline Temperature, $\mathrm{K}$ & $298(2)$ & $298(2)$ & $298(2)$ \\
\hline Crystal system & Monoclinic & Orthorhombic & Monoclinic \\
\hline Space group & $C 2 / c$ & Pna2 $_{1}$ & $C 2 / c$ \\
\hline \multicolumn{4}{|l|}{ Unit cell dimensions } \\
\hline$a, \AA$ & $27.421(1)$ & $9.511(2)$ & $26.957(2)$ \\
\hline$b, \AA$ & $9.9843(4)$ & $9.866(2)$ & $10.0612(9)$ \\
\hline$c, \AA$ & $24.302(1)$ & $13.871(3)$ & $25.526(2)$ \\
\hline$\beta,^{\circ}$ & $119.416(2)$ & & $114.045(3)$ \\
\hline Volume, $\AA^{3}$ & $5795.7(5)$ & $1301.6(5)$ & $6304.5(10)$ \\
\hline$Z$ & 16 & 4 & 16 \\
\hline Density (calculated), $\mathrm{g} / \mathrm{cm}^{3}$ & 1.230 & 1.379 & 1.253 \\
\hline Absorption coefficient, $\mathrm{mm}^{-1}$ & 0.082 & 0.098 & 0.084 \\
\hline$F(000)$ & 2272 & 568 & 2528 \\
\hline Crystal size, $\mathrm{mm}^{3}$ & $0.27 \times 0.25 \times 0.23$ & $0.17 \times 0.13 \times 0.13$ & $0.23 \times 0.21 \times 0.20$ \\
\hline Theta range for data collection, ${ }^{\circ}$ & $2.57-25.50$ & $2.94-26.49$ & $2.48-25.50$ \\
\hline Limiting indices & $\begin{array}{l}-33 \leq h \leq 33,-11 \leq k \leq 12,-29 \leq \\
l \leq 29\end{array}$ & $\begin{array}{l}-11 \leq h \leq 11,-12 \leq k \leq 12,-15 \\
\leq l \leq 17\end{array}$ & $\begin{array}{l}-32 \leq h \leq 31,-12 \leq k \leq 11, \\
-30 \leq l \leq 30\end{array}$ \\
\hline Reflections collected & 119145 & 9350 & 33689 \\
\hline Observed reflections $[I \geq 2 \sigma(I)]$ & 5383 & 2479 & 5875 \\
\hline Data/restraints/parameters & $4421 / 2 / 372$ & $2365 / 2 / 186$ & $2994 / 2 / 410$ \\
\hline$R_{\text {int }}$ & 0.0320 & 0.0205 & 0.0885 \\
\hline Goodness-of-fit on $F^{2}$ & 1.171 & 1.146 & 1.008 \\
\hline Final $R$ indices $[I \geq 2 \sigma(I)]$ & $R_{1}=0.0520, w R_{2}=0.1172$ & $R_{1}=0.0342, w R_{2}=0.0912$ & $R_{1}=0.0532, w R_{2}=0.1079$ \\
\hline$R$ indices (all data) & $R_{1}=0.0684, w R_{2}=0.1366$ & $R_{1}=0.0372, w R_{2}=0.1021$ & $R_{1}=0.1411, w R_{2}=0.1368$ \\
\hline Largest diff. peak and hole & $0.221,-0.153$ & $0.193,-0.338$ & $0.167,-0.147$ \\
\hline
\end{tabular}

In the crystal structure of (1), molecules are linked through intermolecular $\mathrm{N}-\mathrm{H} \cdots \mathrm{O}$ and $\mathrm{C}-\mathrm{H} \cdots \mathrm{O}$ hydrogen bonds (Table 4), to form 1D chains (Fig. 4). In the crystal structure of (2), molecules are linked through intermolecular $\mathrm{O}-\mathrm{H} \cdots \mathrm{O}$ and $\mathrm{N}-\mathrm{H} \cdots \mathrm{O}$ hydrogen bonds (Table 4), to form 1D chains (Fig. 5). In the crystal structure of (3), molecules are linked through intermolecular $\mathrm{N}-\mathrm{H} \cdots \mathrm{O}$ and $\mathrm{C}-\mathrm{H} \cdots \mathrm{O}$ hydrogen bonds (Table 4), to form 1D chains (Fig. 6). Moreover, there are also $\pi$-electron ring $-\pi$-electron ring interactions in the packing structures of the compounds that are specified in Table 5 . 
Table 2. Selected bond lengths $(\AA)$ and angles $\left(^{\circ}\right)$ for the compounds.

\begin{tabular}{|c|c|c|c|}
\hline & (1) & & \\
\hline \multicolumn{4}{|c|}{ Bond distances } \\
\hline C7-N1 & $1.275(3)$ & N1-N2 & $1.377(2)$ \\
\hline $\mathrm{N} 2-\mathrm{C} 8$ & $1.350(3)$ & $\mathrm{C} 8-\mathrm{O} 2$ & $1.226(2)$ \\
\hline $\mathrm{C} 23-\mathrm{N} 3$ & $1.279(2)$ & N3-N4 & $1.369(2)$ \\
\hline N4-C24 & $1.352(2)$ & $\mathrm{C} 24-\mathrm{O} 4$ & $1.229(2)$ \\
\hline \multicolumn{4}{|c|}{ Bond angles } \\
\hline C7-N1-N2 & $117.8(2)$ & N1-N2-C8 & $118.7(2)$ \\
\hline $\mathrm{N} 2-\mathrm{C} 8-\mathrm{O} 2$ & $122.7(2)$ & $\mathrm{N} 2-\mathrm{C} 8-\mathrm{C} 9$ & $114.1(2)$ \\
\hline C23-N3-N4 & $118.6(2)$ & N3-N4-C24 & $118.2(2)$ \\
\hline \multirow[t]{2}{*}{ N4-C24-O4 } & $120.9(2)$ & N4-C24-C25 & $116.6(2)$ \\
\hline & (2) & & \\
\hline \multicolumn{4}{|c|}{ Bond distances } \\
\hline C8-N1 & $1.279(2)$ & N1-N2 & $1.376(2)$ \\
\hline $\mathrm{N} 2-\mathrm{C} 9$ & $1.352(2)$ & $\mathrm{C} 9-\mathrm{O} 2$ & $1.241(2)$ \\
\hline \multicolumn{4}{|c|}{ Bond angles } \\
\hline C8-N1-N2 & $118.2(1)$ & N1-N2-C9 & $118.2(1)$ \\
\hline \multirow[t]{2}{*}{ N2-C9-O2 } & $120.9(2)$ & N2-C9-C10 & $116.7(2)$ \\
\hline & (3) & & \\
\hline \multicolumn{4}{|c|}{ Bond distances } \\
\hline C8-N1 & $1.278(3)$ & N1-N2 & $1.372(2)$ \\
\hline $\mathrm{N} 2-\mathrm{C} 9$ & $1.361(3)$ & $\mathrm{C} 9-\mathrm{O} 2$ & $1.232(3)$ \\
\hline $\mathrm{C} 25-\mathrm{N} 4$ & $1.276(3)$ & N4-N5 & $1.379(2)$ \\
\hline $\mathrm{N} 5-\mathrm{C} 26$ & $1.360(3)$ & $\mathrm{C} 26-\mathrm{O} 4$ & $1.231(3)$ \\
\hline \multicolumn{4}{|c|}{ Bond angles } \\
\hline C8-N1-N2 & $117.8(2)$ & N1-N2-C9 & $118.7(2)$ \\
\hline N2-C9-O2 & $120.6(2)$ & N2-C9-C10 & $115.5(2)$ \\
\hline C25-N4-N5 & $117.3(2)$ & N4-N5-C26 & $118.3(2)$ \\
\hline N5-C26-O4 & $122.1(2)$ & $\mathrm{N} 5-\mathrm{C} 26-\mathrm{C} 27$ & $114.5(2)$ \\
\hline
\end{tabular}

Table 3. Elemental analysis (\%) for the compounds.

\begin{tabular}{|c|c|c|c|c|c|c|}
\hline & \multicolumn{2}{|c|}{ C } & \multicolumn{2}{c|}{ H } & \multicolumn{2}{c|}{ N } \\
\hline & Calcd & Found & Calcd & Found & Calcd & Found \\
\hline$(1)$ & 71.6 & 71.7 & 6.0 & 6.0 & 10.4 & 10.5 \\
\hline$(2)$ & 66.7 & 66.5 & 5.2 & 5.3 & 10.4 & 10.2 \\
\hline$(3)$ & 68.7 & 68.5 & 6.4 & 6.3 & 14.1 & 14.2 \\
\hline
\end{tabular}

Table 4. Hydrogen-bond geometry $\left(\AA,{ }^{\circ}\right)$ of the compounds

\begin{tabular}{|c|c|c|c|c|}
\hline$D-\mathrm{H} \cdots A$ & $\begin{array}{c}d(D-\mathrm{H}) \\
(\AA)\end{array}$ & $\begin{array}{c}d(\mathrm{H} \cdots A) \\
(\AA)\end{array}$ & $\begin{array}{c}d(D \cdots A) \\
(\AA)\end{array}$ & $\begin{array}{c}\text { Angle }(D- \\
\mathrm{H} \cdots A)\left({ }^{\circ}\right)\end{array}$ \\
\hline$(1)$ & & & & \\
\hline $\mathrm{N} 4-\mathrm{H} 4 \cdots \mathrm{O} 2^{\mathrm{i}}$ & $0.90(1)$ & $2.15(1)$ & $3.025(2)$ & $165(2)$ \\
\hline $\mathrm{N} 2-\mathrm{H} 2 \cdots \mathrm{O} 4^{\mathrm{ii}}$ & $0.90(1)$ & $1.99(1)$ & $2.869(2)$ & $168(2)$ \\
\hline $\mathrm{O} 1-\mathrm{H} 1 \cdots \mathrm{N} 1$ & 0.82 & 1.88 & $2.598(2)$ & 145 \\
\hline $\mathrm{O} 3-\mathrm{H} 3 \cdots \mathrm{N} 3$ & 0.82 & 1.86 & $2.581(2)$ & 146 \\
\hline $\mathrm{C} 13-\mathrm{H} 13 \cdots \mathrm{O} 1^{\mathrm{iii}}$ & 0.93 & 2.51 & $3.351(2)$ & 151 \\
\hline $\mathrm{C} 23-\mathrm{H} 23 \cdots \mathrm{O}^{2} \mathrm{i}$ & 0.93 & 2.58 & $3.374(2)$ & 143 \\
\hline$(2)$ & & & & 145 \\
\hline $\mathrm{O} 1-\mathrm{H} 1 \cdots \mathrm{N} 1$ & 0.82 & 1.90 & $2.616(2)$ & 145 \\
\hline $\mathrm{O} 3-\mathrm{H} 3 \cdots \mathrm{O} 2^{\mathrm{iv}}$ & 0.82 & 2.01 & $2.764(2)$ & 154 \\
\hline $\mathrm{N} 2-\mathrm{H} 2 \cdots \mathrm{O} 2^{\mathrm{v}}$ & $0.90(1)$ & $2.16(1)$ & $3.046(2)$ & $168(3)$ \\
\hline$(3)$ & & & & 146 \\
\hline $\mathrm{N} 5-\mathrm{H} 5 \cdots \mathrm{O} 2^{\mathrm{i}}$ & $0.90(1)$ & $2.03(1)$ & $2.925(3)$ & $170(2)$ \\
\hline $\mathrm{N} 2-\mathrm{H} 2 \cdots \mathrm{O} 4^{\mathrm{vi}}$ & $0.90(1)$ & $2.23(1)$ & $3.102(2)$ & $163(2)$ \\
\hline $\mathrm{O} 3-\mathrm{H} 3 \cdots \mathrm{N} 4$ & 0.82 & 1.90 & $2.611(3)$ & 145 \\
\hline $\mathrm{O} 1-\mathrm{H} 1 \cdots \mathrm{N} 1$ & 0.82 & 1.87 & $2.588(3)$ & 146 \\
\hline $\mathrm{C} 8-\mathrm{H} 8 \cdots \mathrm{O} 4^{\mathrm{vi}}$ & 0.93 & 2.59 & $3.396(3)$ & 146 \\
\hline $\mathrm{C} 23-\mathrm{H} 23 \cdots \mathrm{O} 1^{\mathrm{i}}$ & 0.93 & 2.55 & 3.448 & 164 \\
\hline
\end{tabular}

Symmetry codes: i) $-1+x, y, z$; ii) $1+x, 1+y, z$; iii) $2-x, y, 1 / 2-z$; iv) 2 $-x, 1-y,-z ; \mathrm{v})-1 / 2+x, 1 / 2-y, z ; \mathrm{vi}) 1+x,-1+y, z$.

Table 5. $\pi-\pi$ Interactions $(\AA)$ of compounds.

\begin{tabular}{|c|c|c|c|}
\hline$(1)$ & & & \\
\hline$C g 1 \cdots C g 3^{\text {vii }}$ & $4.675(3)$ & $C g 2 \cdots C g 2^{\text {viii }}$ & $4.918(3)$ \\
\hline$C g 3 \cdots C g 3^{\text {ix }}$ & $4.784(3)$ & & \\
\hline$(2)$ & & & \\
\hline$C g 4 \cdots C g 5^{\mathrm{x}}$ & $4.774(3)$ & $C g 5 \cdots C g 4^{\mathrm{xi}}$ & $4.975(3)$ \\
\hline$(3)$ & & & \\
\hline$C g 6 \cdots C g^{6 \mathrm{i} x}$ & $3.782(3)$ & $C g 7 \cdots C g 6^{\mathrm{ix}}$ & $4.738(3)$ \\
\hline
\end{tabular}

$C g 1, C g 2$ and $C g 3$ are the centroids of the $\mathrm{C} 9-\mathrm{C} 14, \mathrm{C} 17-\mathrm{C} 22$ and $\mathrm{C} 25-$ C30 benzene rings, respectively, in (1). Cg4 and $\mathrm{Cg} 5$ are the centroids of the $\mathrm{C} 1-\mathrm{C} 6$ and $\mathrm{C} 10-\mathrm{C} 15$ benzene rings, respectively, in (2). $\mathrm{Cg} 6$ and $\mathrm{Cg} 7$ are the centroids of the $\mathrm{C} 10-\mathrm{C} 15$ and $\mathrm{C} 27-\mathrm{C} 32$ benzene rings, respectively, in (3). Symmetry codes: vii) $1 / 2+x, 1 / 2+y, z$; viii) $-x, 1-y,-z$; ix $)-x, y, 1 / 2-z$; x) $-x, 2-y,-1 / 2+z$; xi) $1 / 2-x,-1 / 2+y, 1 / 2+z$. 


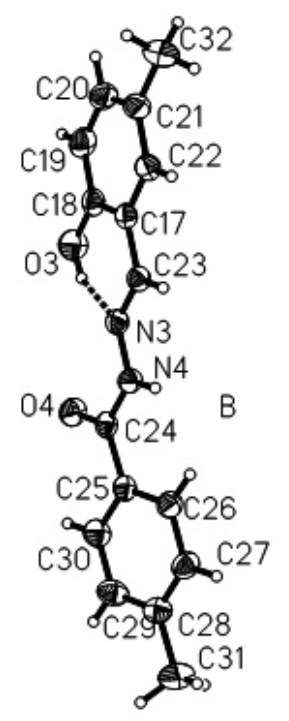

Fig. 1. Molecular structure of (1) showing 30\% probability displacement ellipsoids. Intramolecular hydrogen bonds are drawn as dashed lines.

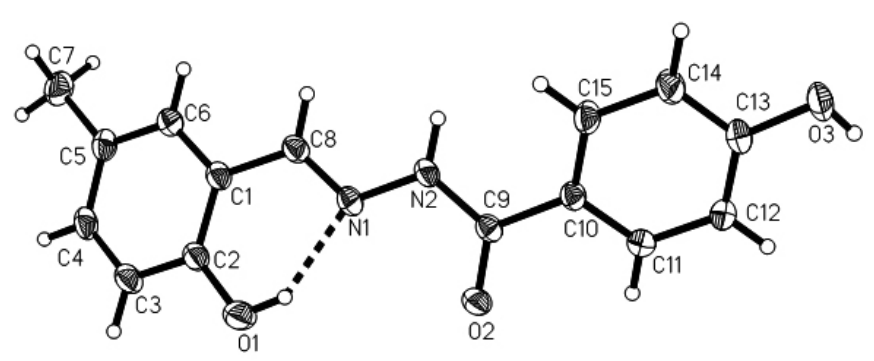

Fig. 2. Molecular structure of (2) showing $30 \%$ probability displacement ellipsoids. Intramolecular hydrogen bond is drawn as a dashed line.
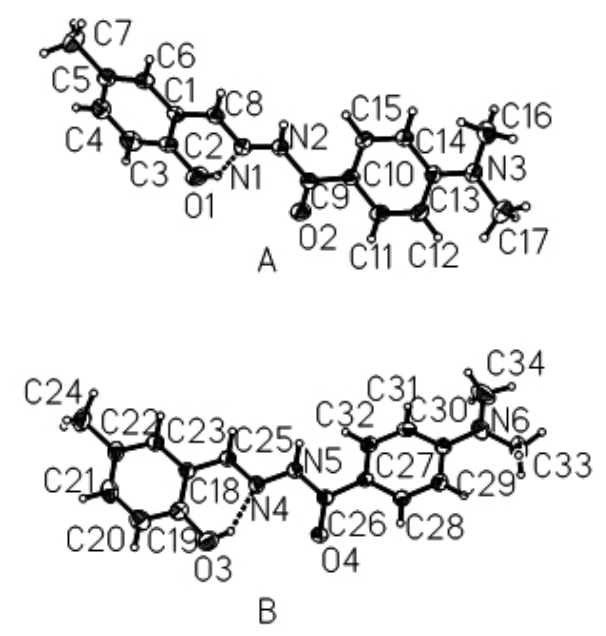

Fig. 3. Molecular structure of (3) showing $30 \%$ probability displacement ellipsoids. Hydrogen bonds are drawn as dashed lines.

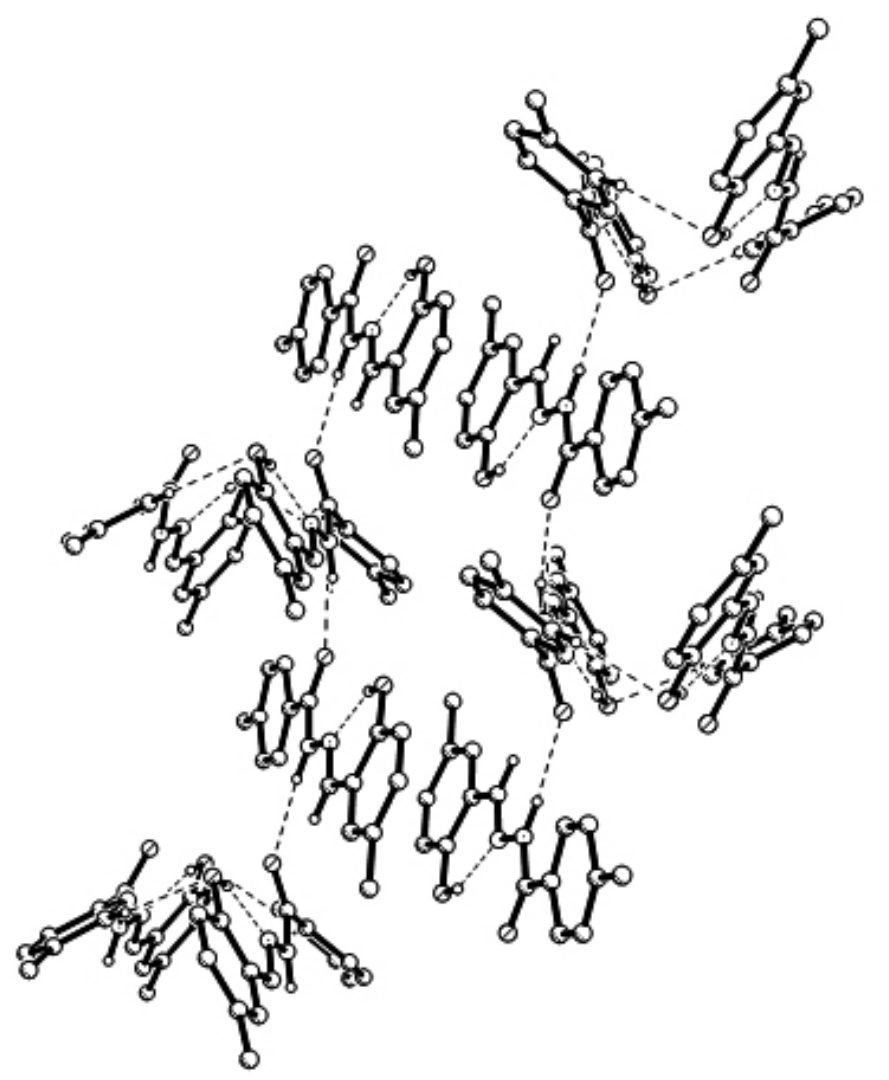

Fig. 4. Molecular packing of (1). Hydrogen bonds are shown as dashed.

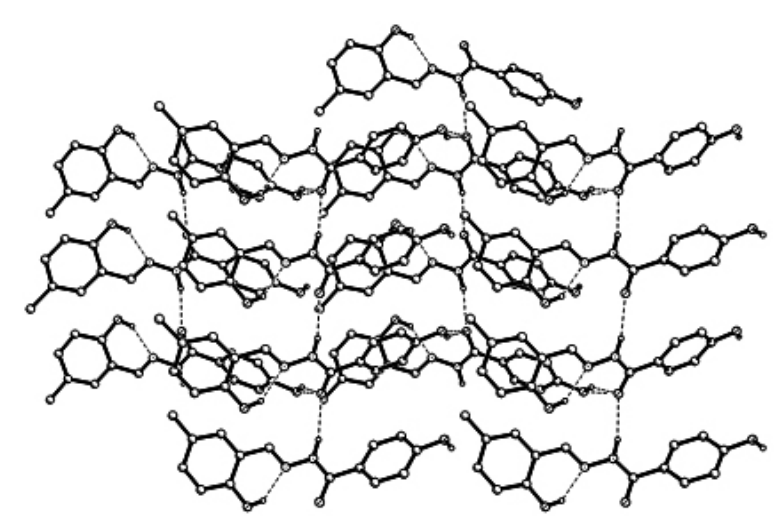

Fig. 5. Molecular packing of (2). Hydrogen bonds are shown as dashed lines. 


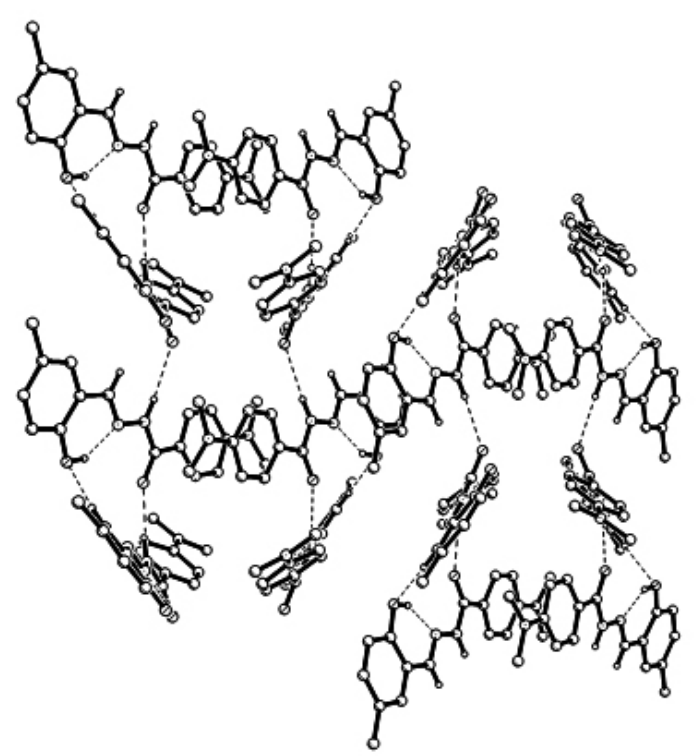

Fig. 6. Molecular packing of (3). Hydrogen bonds are shown as dashed lines.

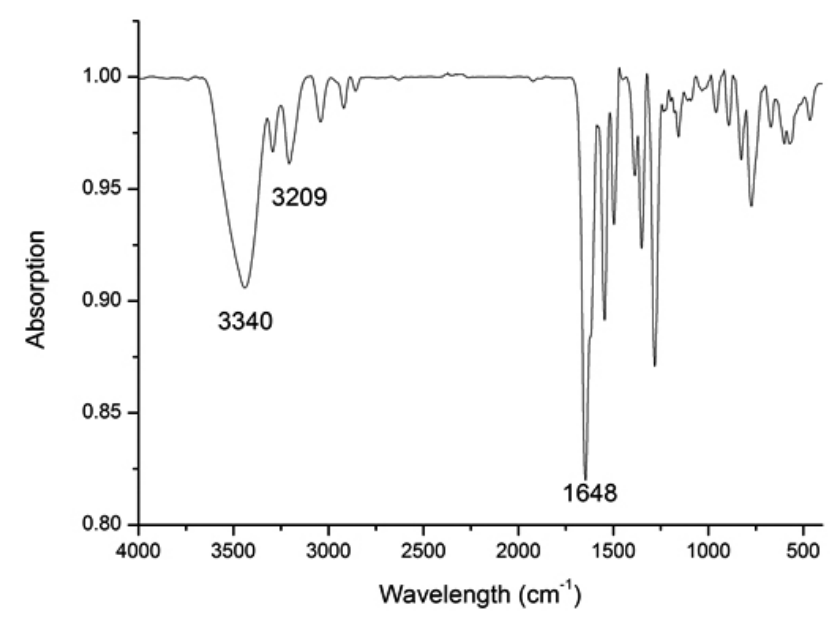

Fig. 7. IR spectrum of (1).

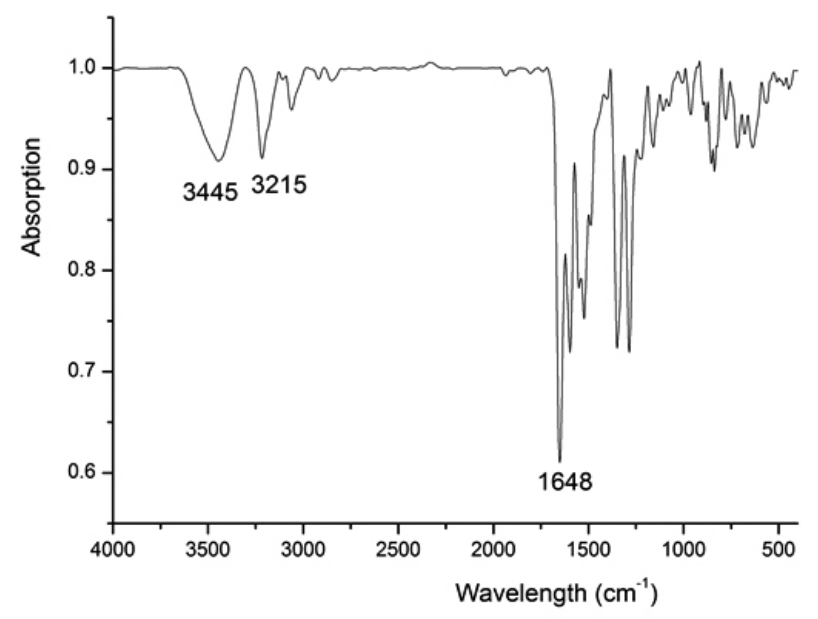

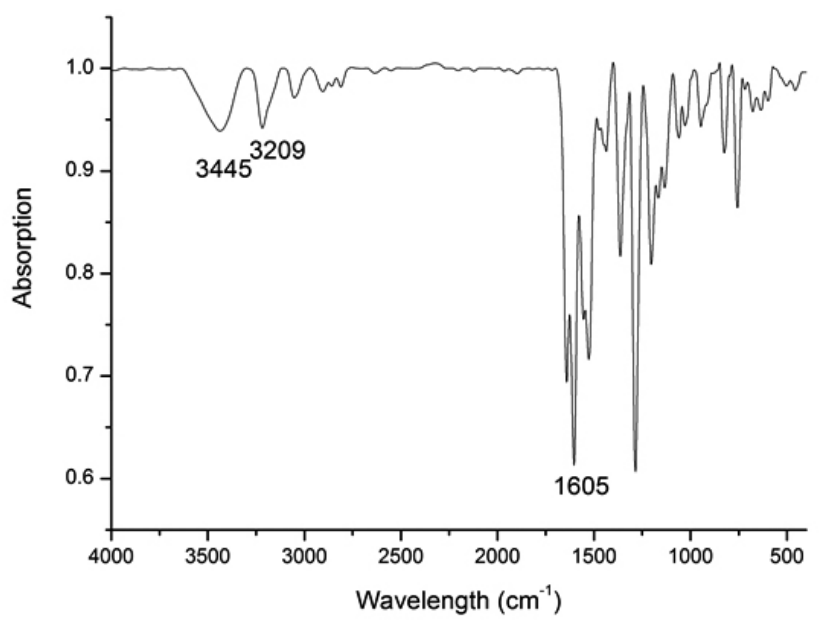

Fig. 9. IR spectrum of (3).

IR spectra

IR spectra of the compounds (1), (2) and (3) are shown in Figures 7, 8 and 9 , respectively. The characteristic intense bands in the range $1648 \mathrm{~cm}^{-1}$ for (1) and (2), and $1605 \mathrm{~cm}^{-1}$ for (3) were generated by the $v(\mathrm{C}(\mathrm{O})-\mathrm{NH}-\mathrm{C}=\mathrm{N})$ vibrations. In the spectra of the compounds, there were broad absorptions in the range $3350-3470 \mathrm{~cm}^{-1}$, which can be attributed to the hydrogen-bonded phenol groups. The sharp bands at $3209 \mathrm{~cm}^{-1}$ for (1), $3215 \mathrm{~cm}^{-1}$ for (2), and $3227 \mathrm{~cm}^{-1}$ for (3) were assigned to the $v(\mathrm{~N}-\mathrm{H})$ vibrations.

Supplementary material

Crystallographic data for the structures reported in this paper have been deposited with the Cambridge Crystallographic Data Centre as supplementary publication nos. 965347 (1), 965348 (2), and 965349 (3). Copies of available material can be obtained, free of charge, on application to the Director, CCDC, 12 Union Road, Cambridge CB2 1EZ, UK, (fax: +44-(0)1223-336033 or e-mail: deposit@ccdc.cam.ac.uk).

\section{ACKNOWLEDGMENTS}

Project supported by the Agricultural University of Hebei.

\section{REFERENCES}

1. Narang R, Narasimhan B, Sharma S (2012) Curr Med Chem 19:569

2. Kumar D, Kumar NM, Ghosh S, Shah K (2012) Bioorg Med Chem Lett 22:212

3. Torres E, Moreno, Ancizu S, Barea C, Galiano S, Aldana I, MongeA, Perez-Silanes S (2011) Bioorg Med Chem Lett 21:3699

4. Zhang M, Xian D-M, Li H-H, Zhang J-C, You Z-L (2012) Aust J Chem $65: 343$

5. Angelusiu MV, Barbuceanu SF, Draghici C, Almajan GL (2010) Eur J Med Chem 45:2055

6. Ajani OO, Obafemi CA, Nwinyi OC, Akinpelu DA (2010) Bioorg Med Chem 18:214

7. Sheldrick GM (2008) Acta Crystallogr A64:112

8. Allen FH, Kennard O, Watson DG, Brammer L, Orphen AG, Taylor R (1987) J Chem Soc Perkin Trans 2:S1

9. Lei Y, Li T-Z, Fu C, Guan X-L, Tan Y (2011) J Chem Crystallogr 41:1707

10. Wei Y-J, Wang F-W (2011) J Struct Chem 52:755

11. Wang X-L, You Z-L, Wang C (2011) J Chem Crystallogr 41:621.

Fig. 8. IR spectrum of (2). 